\section{In the name of genetics}

\author{
Dorothy Nelkin
}

Exploding the Gene Myth. By Ruth Hubbard and Elijah Wald. Beacon: 1993. Pp. 206. \$24.

Biology as Ideology: The Doctrine of DNA. By Richard C. Lewontin. HarperPerennial: 1993. Pp. 128. $\$ 10$ (pbk).

THE Human Genome Project has encouraged, with research funds, studies of the social implications of a rapidly developing science that promises to reveal the essence of life and to predict our future fate. Much of this work, by sociologists, ethicists and historians, has been critical, focusing on several related themes. Science, and in particular genetics, is shaped by social forces and ideological agendas: the history of eugenics is the usual example. Advances in genetics have troublesome ethical implications, bearing on questions of privacy, justice and equity: the key words are genetic discrimination. And the implications of genetics must be seen in a political context, for the use of genetic information is tied to prevailing political and economic ideologies and the interests of social institutions.

These two books also explore these themes, but two of the authors, Hubbard and Lewontin, are neither philosophers nor social scientists but biologists critics of their own colleagues. How does this influence their perspective?

Hubbard and Wald's agenda is evident in the subtitle of their book: "How genetic information is produced and manipulated by scientists, physicians, employers, insurance companies, educators, and law enforcers." Writing in accessible terms, they offer a broad overview of the science of genetics and its social implications. Their intention is to convince readers that genetics will have a powerful influence on their lives and that scientists cannot be trusted to protect them: "We cannot just sit by as passive worshipers or victims". They describe their book as "a basic survival handbook".

Their task is to explode "gene myths" - that genes are an all powerful basis of health and disease, that biotechnology is the "wave of the future", that science is immune to political and social pressure, that organisms can be explained in terms of their molecules, that chronic conditions such as cancer can be explained in terms of inherited tendencies. Their point is that these myths developed in the political context of inequality in the distribution of power and resources, in the economic context of capitalism with its market pressures, and, above all, in the social context of a science that is controlled by commercial connections.
Scientists, they argue, have interests in defining normality and deviance, health and disease, in terms of genetics rather than social or environmental conditions.

The authors dwell on the conflicts of interest arising from the commercialization of genetics and biotechnology. Scientists, economically linked to their enterprise and preoccupied with patents, cannot be trusted to protect the public interest even when they seem to try. The authors suspect the programme funded by the National Institutes of Health on the social and ethical implications of genetics of "putting the Human Genome Project in a position to supervise what questions are asked". So they conclude with a social policy agenda. Citizens cannot leave critical decisions in the hands of experts. They must be vigilant, informed and directly involved in decisions about the development and application of science.

Lewontin's book, a collection of his essays on the ideological basis of contemporary biology, is more about political philosophy than social policy. He too explodes the myths encouraged by scientific ways of thinking: that it is possible to understand the world in reductionist terms, that there are clear distinctions between cause and effect, that the world is made up of bits and pieces that can be isolated and studied in isolation. These beliefs, he argues, are just as ideological as the holistic world view of a more mystical, premodern age. cal ideologues" who perpetuate the belief that science offers simple explanations for social problems. Rather, he says that "things are complicated, uncertain, and messy, that no simple rule or force will explain the past and predict the future of human existence". There is, in fact, only a limited relationship between scientific understanding and the social practices that draw support from science. As history shows, science has ideological and social purposes; it can lend legitimacy to social policies, provide legitimation for social inequities and justify power relationships on the basis of natural categories. Lewontin describes how the genetic world-view - deterministic and reductionist - encourages the view that human life is what it has to be. To suggest that everything we are - our health, our wealth, the very structure of
Lewontin is highly critical of "biologi- society - is encoded in our DNA is simply to justify the status quo.

Lewontin counters such thinking with an interactionist perspective. Denying the distinctions between nature and nurture and between biology and ideology, he calls for "an entirely new level of causation" based on the complex interaction between the biology of living organisms and their environment. And science too must be viewed as an interaction between scientists and society. Just as science affects society, so scientific priorities and ideas are shaped by social and economic forces. For scientists are social beings, their ideas moulded partly by social experience.

That Hubbard and Lewontin are biologists by profession shows up in several ways. They are especially skilled at popularizing the technical aspects of genetics. But, beyond general references to market forces and social ideologies, they are not inclined to analyse the structural features of a society that lends credence to gene myths. While proposing solutions through public participation, they feel no need to define appropriate constituencies or organizational strategies. Nor do they deal with the real dilemmas of participation that have been the focus of considerable research. And they can gloss over the social forces that contribute to the appeal of reductionist and deterministic ideas. Indeed, my research on images of the gene in popular culture is revealing trends that make me wonder about the results of public participation. Would it encourage decisions that these authors (and I) would really welcome?

Finally, these books are less constrained and more cynical in their criticism of science than those written by nonscientists. Is it because Hubbard and Lewontin are insiders in the scientific enterprise, protected by their credentials and free to debunk their colleagues? Or are they reflecting growing disaffection among scientists with recent changes in their profession? Science, and especially genetics, has moved from academe to the commercial world, tied to private corporations, wedded to profits. As its image as an independent search for truth has changed, scientists have had mixed reactions. Some respond by trying to capture media attention: thus the gene becomes a "master molecule" and the genome the "Book of Man". Others, disillusioned with their colleagues, react with cynicism and dismay. The perspectives of these two books is clearly influenced by the broader tensions in the scientific community over the changing character of science.

Dorothy Nelkin is in the Department of Sociology, New York University, New York, New York 10003, USA. 